UDC 378.147:811.111

DOI https://doi.org/10.32838/2710-4656/2021.1-2/15

Dychka N.I.

National Technical University of Ukraine "Igor Sikorsky Kyiv Polytechnic Institute"

Gural O. I.

National Technical University of Ukraine "Igor Sikorsky Kyiv Polytechnic Institute"

\title{
LINGUISTIC FEATURES OF WRITING TECHNICAL DOCUMENTS IN ENGLISH
}

The article is devoted to the linguistic features of English technical documentation. The analysis is performed on the example of such a document as the software requirements specification (SRS). The characteristic of the software requirements specification according to lexical, grammatical and syntactic features is presented. The research is done on the base of 120 SRSs taken from the computer companies and firms. Text material, subtext and type of technical text are considered. The paper describes the vocabulary of the technical documentation. It is noted that integral requirement for the SRS is the use of terms and also general vocabulary. The paper states that the vocabulary of the software requirements specification is rich in the special cliches, conjunctions, pronouns, abbreviations, acronyms, symbols, definitions, multicomponent phrases, continuances, directives, stylistically neutral, general scientific, specialized vocabulary and phrases. Grammatical means of the text of scientific style, scientific and technical substyle of the SRS are considered. They are The Present Simple, The Future Simple in active and passive voice, adjectives, gerund, infinitive and infinitive constructions, conditional sentences (with a real condition), modal verbs with passive constructions. Syntactic features of the SRS are described: clear compositional form, separation of one thought from another, numbering of separate parts of the statement, impersonal style of sentence presentation, use of indirect speech, narrative sentences, sentences with rows of homogeneous members.

The research is conducted for the undergraduate students who study computer science or computer engineering. The lexical, grammatical and syntactic features are analyzed with examples in the computer field of knowledge. The examples are taken from the real SRSS. The lexical, grammatical and syntactic means of the SRSs are summarized in the table. Conclusions have been made and further aspects of the research are outlined.

Key words: software requirements specification, IT students, vocabulary, grammar, syntax.

Formulation of the problem. The entry of Ukraine into the European educational space and the expansion of international relations encourage society to prepare highly skilled IT specialists who speak English on the professional level what is accompanied by significant changes in qualification requirements, in pedagogical theory and in teaching practice of technical specialties' students.

Graduates of higher technical institutions will deal with foreign language technical documentation in their professional activities, the preparation of which requires mastery of written speech at a sufficient professional level. Specialists of enterprises and companies often have to cooperate with foreign partners, create a software requirements specification for the joint scientific and technical developments. But often programmers have a problem because firms do not have the standards to develop specifications, or do not consider it necessary [11, p. 30]. This situation complicates the process for programmers to create proper software development, making it longer. There is also a lack of literature on how to write SRSs, especially in terms of language. Therefore, this type of writing is extremely important for the future professional activity in IT.

The aim of the paper. The aim of the paper is to determine linguistic features of the software requirements specification. And also to analyze the specifics of English technical documentation. The paper gives advice how to achieve success in writing English technical documentation.

Before considering the specification of requirements in the linguistic field, we will give its definition.

Under the specification of software requirements, we understand the source document for software, hardware and software development, which defines the obligatory requirements for the software product, the results that must be achieved during the project. 
That is, the SRS - a document that defines the procedure and conditions of the contract, contains the purpose, objectives, principles of implementation, results and timing of work [3, p. 7]. This means that such a document reflects the facts of production activities, identified, processed and expressed in writing by the student.

Analysis of recent research and publications. In science, art, industrial production, in the field of various professions, special vocabulary is used, much of which is terminological. Terminological vocabulary - higher, compared to common vocabulary, the category of names of objects and phenomena surrounding reality. The term, unlike the ordinary word, not only names, but also logically exhaustively and precisely defines the concept, it gives a multifaceted, voluminous and concise description of the object or phenomenon, while containing more information than any lexical unit [10, p. 12]. Researchers N. S. Bukhtiyarov, I. M. Solovyov, E. F. Skorokhodko, S.V. Podolkova, V.A. Sudovtsev, E.K. Savinov, V. K. Kolobayev point to the saturation of the scientific and technical texts in terms. The specificity of students' research is the use of terms that belong to the direction of teaching "Computer Science": register bits, handler, memory controller and so on. The terms allow to narrow and specify the problem. Unambiguity and conciseness are the basic requirements for terms. As noted V.A. Sudovtsev the meaning of the term for a specialist is equivalent to the concept.

Presenting main material. We have analyzed 120 SRSs taken from the computer companies and firms. An integral requirement for the SRS is the use of not only special but also general vocabulary. The activities of future specialists in computer technology are directly related to the computer environment, so professionally oriented texts are filled with words that belong to the computer field of knowledge. For example, common computer terms include computer system, computer hardware, service, and so on.

It should be noted that the vocabulary of the software requirements specification is rich in the following clichés: but not limited to, in particular, at a minimum, as appropriate. The use of neutral vocabulary (provides, explains, defines, reviews, describes) helps the author to achieve objectivity and generalization.

A specific feature of the SRS is phraseology. There are no figurative constant phrases here, there are no inversions with reduced stylistic color. But stylistically neutral and interstylistic phraseologies are very widely represented: to be of importace, occupy the post, sphere of application, etc. There are standard inversions of speech, steel in nature, which contain prepositions that indicate the nature of motivation: in connection with the order, in accordance with, in order to provide technical assistance, etc. Prepositions are also used: for, during, in, since, till.

It should also be noted the noun nature of the SRSs. The same noun in the texts of the specification can be repeated even in adjacent sentences and not be replaced by a pronoun. The SRSs in the field of computer engineering is characterized by the use of multicomponent phrases, they avoid redundancy $[5$, p.3]. These are phrases that are formed - Noun + Noun: debugging support, memory roll-over. Complex phrases, which consist, for example, of a series of nouns -1 Noun + Noun + Noun (keyboard controller code, hardware suspend requests); - Noun + Noun + Noun + Noun (system management status registers).

A common means of information optimization of SRS are professional (DB - Database, SOP special operating provisions) and Latin (e.g. - for example, etc. -etcetera) abbreviations.

Nouns are used to name people on the basis of some action or relationship: user, specwriter, programmer, head of the project.

Verbal nouns (gerund, adjective) are widely used: using, used, displayed, clicking.

Grammatical means of the text of scientific style, scientific and technical substyle are considered by many researchers (N.S. Bukhtiyarov, I.R. Halperin, M.B. Vorobyova, L.V. Slavgorodskaya, V.V. Kuskov, I. Yu. Tarasova) specific and noteworthy. The infinitive and infinitive constructions are very often used too: In designing products, it helps to imagine a few real life stories of how actual (stereotypical) people would use them.

English-language software requirements are characterized by sentences in the imperative mood (Enter your password! Click here to sign up!). This is not typical of Ukrainian-language software requirements.

Among the English species-temporal forms of verbs, the most widely used in the specification of software requirements now (often - The Present Indefinite, but possibly also - The Future Indefinite):

e.g. The right side of the screen behaves the same way as described previously under Home Page. / The vehicle's exhaust system will power the $A B C$ widget.

Most often The Present Indefinite and The Future Indefinite are used in the passive form:

e.g. Programming is controlled by the keyboard Clock Control Register. / Each bit in this register is associated with an interrupt request. 
SRSs are saturated with modal verbs must, mustn 't, shall, shouldn't, can, can't, have to:

e.g. It should be at least 800 pixels from the left border of the animation and 600 pixels from the top. / The rigidity of the machine must be such that its deformations under maximum load are negligible.

Also the SRS is characterized by the use of passive structures, especially Modal + Passive Infinitive:

e.g. The keyboard controller can be divided by 2, 4 or stopped. / These bits should be programmed to be zero.

There are adjectives in the SRSs (Participle 1, Participle 2), gerund and adjective and gerund inversions:

e.g. The signal generated by this pin is a toggle. / Unused timers should be masked by setting the corresponding timer enable bit to zero.

Conditional sentences can also be used in the specification:

e.g. Contact Customer Support if you get any other error. / Each local standby timer will not start counting until two events occur.

Along with lexical and grammatical means, the syntactic organization of the software requirements specification also has its peculiarities. The specification of software requirements has a fairly clear strict compositional form. The compositional structure of utterances in the style of scientific speech obeys the principle of clear separation of one thought from another. This clarity finds its maximum expression in the numbering of individual parts of the statement.

As for the syntactic features of scientific and technical texts, they are characterized by long sentences, with an extremely extensive system of connective communication. Sometimes one sentence covers all the terms of the agreement. The connections between sentences reflect, as we know, the real connections between the expressed concepts. This connection is especially clear in the presence of appropriate connectors (e.g. This spec does not discuss the algorithms used by the time calculation engine, which will be discussed elsewhere.).

In simple sentences, usually: a) the subject is before the predicate, followed by subordinate clauses; b) definition before the denoted word; c) the circumstance is closer to the defined word; d) introductory words at the beginning of the sentence (The graphics and layout of the screens is shown here merely to illustrate the underlying functionality).

Complex sentences with conjunctive (and, but) and subjunctive (because, so, as) conjunctions help to follow the logic in the information presentation. e.g. Because of the high similarity between the various screens, some system of includes should be used on the server so that if the name of the service changes, or if we can 't purchase the domain name we want, we'll be able to change all the screens in one place.

A feature of the syntax of the SRS is the predominant use of indirect speech.

Narrative sentences, sentences with rows of homogeneous members are met in the SRSs. The specification contains a large amount of information in one sentence. The result is a complication of the syntactic structure. The structural organization of the SRS is reflected in a clear compositional structure, division into sections, subsections, which is defined by the IEEE-830 standard (Std 830-1998).

Thus, we have described the vocabulary met in the SRSs, summarized its lexical, grammatical and syntactic features.

Summarizing the description of the linguistic features of the SRS, we can summarize its lexical, grammatical and syntactic tools in table 1 .

Table 1

\section{Linguistic features of the SRS text}

\begin{tabular}{|c|c|}
\hline $\begin{array}{l}\text { Lexical: } \\
\text { Conjunctions, } \\
\text { pronouns, clichés, } \\
\text { terminology, } \\
\text { abbreviations, } \\
\text { acronyms, symbols, } \\
\text { definitions, } \\
\text { multicomponent } \\
\text { phrases, } \\
\text { continuances, } \\
\text { directives, } \\
\text { stylistically neutral, } \\
\text { general scientific, } \\
\text { specialized } \\
\text { vocabulary. }\end{array}$ & $\begin{array}{l}\text { Syntactic: } \\
\text { Clear compositional form. } \\
\text { Separation of one thought from } \\
\text { another. } \\
\text { Numbering of separate parts } \\
\text { of the statement. } \\
\text { Impersonal style of sentence } \\
\text { presentation (the position of the subject } \\
\text { is occupied by it or there). } \\
\text { Use of indirect speech, narrative } \\
\text { sentences, sentences with rows } \\
\text { of homogeneous members. } \\
\text { In simple sentences: } \\
\text { the subject stands before } \\
\text { the predicate, followed by } \\
\text { the subordinate clauses; } \\
\text { definition - before the denoted } \\
\text { word; } \\
\text { circumstance - closer to a certain } \\
\text { word; } \\
\text { introductory words - } \\
\text { at the beginning of the sentence. }\end{array}$ \\
\hline
\end{tabular}

\section{Grammatical:}

The Present Simple, The Future Simple in active and passive voice

Adjectives, Gerund, Infinitive and Infinitive

Constructions

Conditional sentences (with a real condition)

Modal verbs with Passive Constructions

Thus, we have summarized the linguistic features of the text of the software requirements specification in the table. 
Conclusions. We have analysed the characteristics of the software requirements specification in the linguistic hierarchy. Also described the vocabulary of the technical documentation; generalized lexical, grammatical and syntactic features of the specification; identified features of the SRS. This will allow us to outline the basic requirements for writing SRS, to create a system of exercises to improve skills and abilities of undergraduates to write a technical documentation in English.

1. Silva, A. R., et al. (2015). A Pattern Language for Use Cases Specification, in Proceedings of EuroPLOP'2015, ACM.

2. Silva, A. R. (2015). Towards a Framework for Requirements Specifications with Increased Quality, in Lecture Notes in Business Information Processing (LNBIP), LNBIP 227, Springer.

3. Ferreira, D., Silva, A. R. (2013) RSL-IL: An Interlingua for Formally Documenting Requirements, in Proc. of the of Third IEEE International Workshop on Model Driven Requirements Engineering, IEEE CS.

4. IEEE 1998. IEEE Std 830-1998, IEEE Recommended Practice for Software Requirements Specifications. URL : http://ieeexplore.ieee.org.

5. Durán, A., Bernárdez, B., Toro, M., Corchuelo, R., Ruiz, A., \& Pérez, J. (1999). Expressing customer requirements using natural language requirements templates and patterns. In IMACS/IEEE CSCC'99 Proceedings.

6. Гальперин И.Р. Текст как объект лингвистического исследования/ И.Р. Гальперин. Москва : Наука, 1981. $139 \mathrm{c}$.

7. Колобаев В.К. Функциональный анализ слов широкой семантики в английской научной литературе. Вопросы анализа спещиального текста. Уфа (Башкирский гос. Университет), 1983. 143 с.

8. Савинова Е.К. Особенности словообразовательных средств выражения категории локативности в общеупотребительной и терминологической лексике английского языка. Функииональныле стили: лингвометодические аспекты / Отв. ред. М.Я. Цвиллинг. Москва : Наука, 1985. 239 с.

9. Судовцев В.А. Науково-технічна інформація та переклад: навч. посібн. Москва : Вища школа, 1989. 232 с.

10. Мазунова Л.К. Система овладения культурой иноязычного письма в языковом вузе : дис. ... доктора пед. наук : 13.00.02. Москва, 2005. 319 с.

11. Хевко І.В., Гілтай Л.С. Формування готовності майбутніх фахівців комп'ютерних технологій до використання цифрових освітніх технологій. Наукові записки: [збірник статей]. Національний педагогічний університет імені Драгоманова. Випуск CXLVII (147). Київ, 2020. С. 30-39. DOI: https: //doi.org/10.31392/NZ-npu-147.2020.04.

\section{Дичка Н. І., ГУраЛЬ О. І. ЛІНГВІСТИЧНІ ОСОБЛИВОСТІ НАПИСАННЯ ТЕХНІЧНИХ ДОКУМЕНТІВ АНГЛІЙСЬКОЮ МОВОЮ}

Стаття присвячена лінгвістичним особливостям англійської технічної документації. Аналіз проводиться на прикладі такого документа, як специфікаиія вимог до програмного забезпечення (ПЗ). У статті представлена характеристика специфікаиії вимог до програмного забезпечення відповідно до лексичних, граматичних та синтаксичних особливостей. Дослідження проводиться на основі 120 специифікацій, взятих у комп'ютерних компаній та фірм. Розглядаються текстовий матеріал, підтекст та тип технічного тексту. У статті описується вокабуляр технічної документачії. Зазначається, що невід 'ємною вимогою до специфікаиії вимог до ПЗ є використання термінів, а також загальна лексика. У статті демонструється, що словниковий склад специфікаиії вимог до програмного забезпечення багатий на спечіальні кліше, сполучники, займенники, скорочення, абревіатури, символи, визначення, багатокомпонентні фрази, продовження, директиви, стилістично нейтральну, загальнонаукову, спеціалізовану лексику та фрази. Розглянуто граматичні засоби тексту наукового стилю, науково-технічного підстилю специфікаиій. Це теперішній простий та майбутній простий в активномута пасивному стані, прикметники, герундії, інфінітивні та інфінітивні конструкції, умовні речення (з реальною умовою), модальні дієслова з пасивними конструкиіями. Описано синтаксичні особливості спеиифікачій: чітка композиційна форма, відокремлення однієї думки від іншої, нумераиія окремих частин висловлювання, безособовий стиль викладу речення, використання непрямої мови, розповідні речення, речення з рядами однорідних членів.

Дослідження проводиться для студентів магістрантів, які вивчають інформатику або обчислювальну техніку. Лексичні, граматичні та синтаксичні особливості аналізуються на прикладах укомп 'ютернійгалузі знань. Приклади взяті з реальних спечифікащій. Лексичні, граматичні та синтаксичні засоби технічного документу узагальнені в таблиці. Зроблено висновки та окреслено подальщі аспекти дослідження.

Ключові слова: специифікачія вимог до програмного забезпечення, студенти IT, словниковий запас, граматика, синтаксис. 